\title{
Drug-Related Orthostatic Hypotension: Beyond Anti-Hypertensive Medications
}

\author{
Giulia Rivasi $^{1} \mathbb{D} \cdot$ Martina Rafanelli $^{1} \cdot$ Enrico Mossello $^{1} \cdot$ Michele Brignole $^{2} \cdot$ Andrea Ungar $^{1}$
}

Published online: 7 September 2020

(c) The Author(s) 2020

\begin{abstract}
Orthostatic hypotension $(\mathrm{OH})$ is an abnormal blood pressure response to standing, which is associated with an increased risk of adverse outcomes such as syncope, falls, cognitive impairment, and mortality. Medical therapy is one the most common causes of $\mathrm{OH}$, since numerous cardiovascular and psychoactive medications may interfere with the blood pressure response to standing, leading to drug-related $\mathrm{OH}$. Additionally, hypotensive medications frequently overlap with other $\mathrm{OH}$ risk factors (e.g., advanced age, neurogenic autonomic dysfunction, and comorbidities), thus increasing the risk of symptoms and complications. Consequently, a medication review is recommended as a first-line approach in the diagnostic and therapeutic work-up of $\mathrm{OH}$, with a view to minimizing the risk of drug-related orthostatic blood pressure impairment. If symptoms persist after the review of hypotensive medications, despite adherence to non-pharmacological interventions, specific drug treatment for $\mathrm{OH}$ can be considered. In this narrative review we present an overview of drugs acting on the cardiovascular and central nervous system that may potentially impair the orthostatic blood pressure response and we provide practical suggestions that may be helpful to guide medical therapy optimization in patients with $\mathrm{OH}$. In addition, we summarize the available strategies for drug treatment of $\mathrm{OH}$ in patients with persistent symptoms despite non-pharmacological interventions.
\end{abstract}

\section{Key Points}

Several cardiovascular and psychoactive medications may alter the blood pressure response to standing, leading to drug-related orthostatic hypotension.

This narrative review provides an overview on cardiovascular and non-cardiovascular medications potentially impairing orthostatic blood pressure.

This review may be helpful to guide medical therapy optimization in patients with an abnormal orthostatic blood pressure response, to minimize the risk of drugrelated orthostatic hypotension.

Giulia Rivasi

giulia.rivasi@unifi.it

1 Syncope Unit and Referral Centre for Hypertension Management in Older Adults, Division of Geriatric and Intensive Care Medicine, Careggi Hospital and University of Florence and Azienda OspedalieroUniversitaria Careggi, Largo Brambilla 3, 50139 Florence, Italy

2 IRCCS, Istituto Auxologico Italiano, Cardiology Unit and Department of Cardiovascular, Neural and Metabolic Sciences, S. Luca Hospital, Milan, Italy

\section{Introduction}

Orthostatic hypotension $(\mathrm{OH})$ is an impaired blood pressure (BP) response to the upright position which is defined by a systolic BP drop $\geq 20 \mathrm{mmHg}$ or by an absolute systolic BP value $\leq 90 \mathrm{mmHg}$ and/or a diastolic BP drop $\geq 10 \mathrm{mmHg}$ within 3 minutes of standing [1, 2]. It is a recognized risk factor for adverse outcomes such as syncope and falls, cardiovascular events (including coronary events, heart failure hospitalization, and stroke), cognitive impairment, and mortality [3-6]. Therefore, $\mathrm{OH}$ diagnostic assessment and treatment play a relevant role in patients' health care and prognosis.

$\mathrm{OH}$ is usually classified according to its etiopathogenesis into neurogenic and non-neurogenic forms. Neurogenic $\mathrm{OH}$ is determined by structural lesions of autonomic pathways, due to disorders affecting central or peripheral autonomic structures (e.g., Parkinson disease, multiple system atrophy, diabetes mellitus, advanced renal failure). By contrast, nonneurogenic $\mathrm{OH}$ forms are attributable to functional causes of autonomic nervous system failure. Among the latter, medications are the most common, particularly in older patients.

With standing, the force of gravity rapidly displaces approximately $10 \%$ of the circulating blood volume (300-800 mL) to the lower body, particularly to the lower 
extremities and splanchnic venous capacitance vessels [1, 7]. As a consequence, venous return and cardiac output are reduced and an ensemble of compensatory responses is activated to prevent a BP fall. The latter usually include an increase in sympathetic outflow and a decrease in vagal nerve activity, leading to an increase in peripheral vascular resistance, heart rate, and cardiac contractility aimed to preserve organ perfusion. Additionally, contractions of lower body muscles (the so-called 'muscle pump') prevent excessive blood pooling in venous vessels and favor venous return to the heart. $\mathrm{OH}$ derives from a failure of the aforementioned compensatory responses, which determines a fall in cardiac output and/or inadequate vasoconstriction. A significant BP fall may also occur in the posture change from a supine to a sitting position. Therefore, measuring sitting BP may be an alternative to standing BP, if the latter is not feasible (e.g., in bedridden patients). Yet, measurements in the sitting position may reduce sensitivity [8] and standing BP should be preferred, whenever possible.

Some medications may interfere with compensatory reflex responses to standing (e.g., sympathetic-mediated vasoconstriction and increased heart rate response and inotropism), while others may increase venous pooling (e.g., vasodilators) and/or induce volume depletion (e.g., diuretics), thus favoring $\mathrm{OH}$.

$\mathrm{OH}$ accounts for $1.3 \%$ of drug adverse reactions and its incidence increases with advancing age [9]. Indeed, agerelated pharmacokinetic changes usually occur that may alter the bioavailability and distribution of medications [10]. Additionally, older adults have a higher susceptibility to $\mathrm{OH}$ due to the frequent coexistence of multiple predisposing factors, such as comorbidities, polypharmacy, and deconditioning. Therefore, drug-related $\mathrm{OH}$ may overlap with other neurogenic and non-neurogenic causes of $\mathrm{OH}$ [9], thus worsening patients' symptoms and the risk of complications. Given all of the above, medical therapy review and optimization should be routinely included in the diagnostic and therapeutic work-up of $\mathrm{OH}$, along with patient's education on lifestyle measures to counteract orthostatic symptoms (e.g., hydration, physical conditioning, use of abdominal binders).

It is well known that many cardiovascular medications may predispose to $\mathrm{OH}$, and it has been shown that withdrawal of antihypertensive medications can decrease BP drop associated with postural change [11]. Yet, potentially hypotensive medications also include psychoactive drugs [12] and opioids [13], which are frequently prescribed in older adults (Fig. 1). In patients with $\mathrm{OH}$, the medication review should be aimed at identifying all the medications potentially impairing orthostatic BP and reassessing their indications and benefits, in order to evaluate withdrawal or dose reduction. In this context, the knowledge of medications potentially influencing orthostatic BP is essential for appropriate management of $\mathrm{OH}$. If symptoms persist despite the reduction of hypotensive medications and adherence to non-pharmacological interventions, specific drug treatment for $\mathrm{OH}$ can be considered, even if evidence-based data are limited.

This narrative review presents an overview on cardiovascular and non-cardiovascular medications potentially causing $\mathrm{OH}$, which may be helpful to optimize medical therapy in patients with an impaired orthostatic BP response. In addition, we summarize the available strategies for drug treatment of $\mathrm{OH}$ in patients with persistent symptoms despite non-pharmacological interventions.
Fig. 1 Medications acting on cardiovascular system (white) and central nervous system (dark grey) potentially responsible for drug-related orthostatic hypotension. $B D Z s$ benzodiazepines

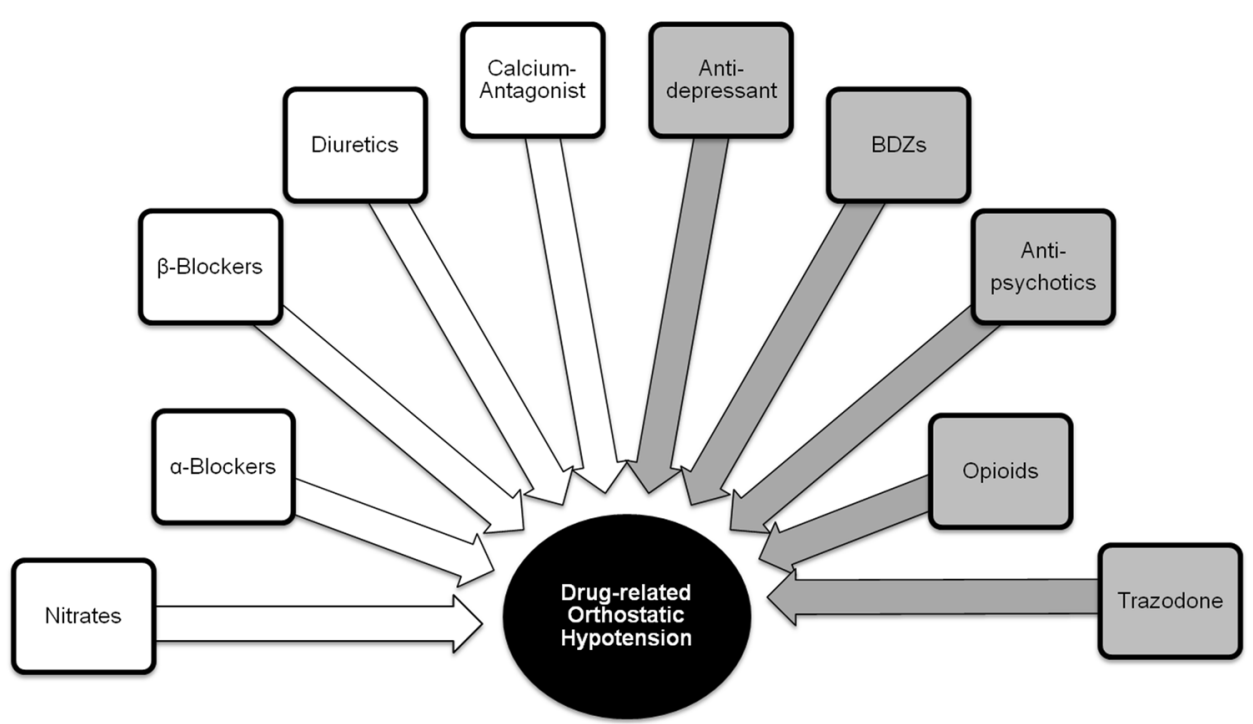




\section{Antihypertensive Medications and Other Cardiovascular Drugs Predisposing to Orthostatic Hypotension (OH)}

\subsection{Diuretics}

Diuretics are considered to be one of the main determinants of drug-related $\mathrm{OH}$. Indeed, diuretics increase urinary sodium excretion and predispose to volume depletion and $\mathrm{OH}$, particularly in older adults. Loop diuretics also increase venous capacitance, thus reducing venous return and cardiac output.

A significant association with $\mathrm{OH}$ (OR 10.44, 95\% CI 1.22-89.08 for loop diuretics [14]; OR 1.25, 95\% CI 1.02-1.53 for thiazide diuretics [15]) and orthostatic syncope (OR 3.73, 95\% CI 1.23-11.28 [16]) is reported by several studies, irrespective of drug dosage [4, 14-17], while this was not confirmed by other population studies [18-23]. Hypokalemia and hyponatremia, which may develop during diuretic therapy, have been reported to be associated with $\mathrm{OH}[24,25]$ and may confound this association. Loop diuretics seem to be more prone than thiazide diuretics to cause volume depletion and should probably be avoided as treatment of hypertension in frailer and older patients, unless specifically indicated (e.g., glomerular filtration rate $<30 \mathrm{~mL} / \mathrm{min}$ ) [26]. Diuretics can generally be safely discontinued in patients with chronic conditions, although a follow-up is necessary to exclude the appearance of heart failure signs [27]. Available data mainly refer to loop and thiazide diuretics, whereas data on potassium-sparing molecules are scarce. In particular, an association between spironolactone and $\mathrm{OH}$ is only reported by Fedorowski et al. [28] (14\% vs 7\% in patients with and without $\mathrm{OH}$, respectively, $p=0.04)$.

\section{2 a-Receptor Blockers}

$\alpha$-Receptor blockers are a known risk factor for $\mathrm{OH}$, which mainly derives from reduced vascular resistance [29-31]. Indeed, $\alpha$-blockers act through a selective blockade of vascular $\alpha 1$-adrenergic receptors, which inhibits the vasoconstrictor effect of catecholamines. $\alpha 1$-Adrenergic receptors are also located in the prostate and bladder neck, where they mediate the tension of smooth muscle. Consequently, $\alpha$-receptor blockers facilitate bladder emptying and improve urinary flow in patients with bladder outflow obstruction, mainly older males with benign prostatic hyperplasia. Three different $\alpha 1$-adrenergic receptors subtypes exist, classified as $\alpha 1 \mathrm{~A}, \alpha 1 \mathrm{~B}$, and $\alpha 1 \mathrm{D}$ [32]. $\alpha 1 \mathrm{~B}$-receptors are located in the vessels, and $\alpha 1 \mathrm{D}$ receptors are located in the detrusor muscle, in the spinal cord, and in afferent nerves originating in the bladder [32]. Benefits on lower urinary tract symptoms derive from $\alpha 1 \mathrm{~A}$ - and $\alpha 1 \mathrm{D}$-receptor inhibition, due to a relaxation of prostate and bladder smooth muscle and the blockade of spinal cord reflex originating from the bladder [32]. Conversely, hypotensive effects and orthostatic BP impairment mainly derive from $\alpha 1 \mathrm{~B}$-receptor blockade. As a consequence, $\mathrm{OH}$ risk varies according to single molecules' affinity for $\alpha 1 \mathrm{~B}$-receptors, with $\alpha 1 \mathrm{~A}$ selective molecules showing a lower risk of orthostatic BP impairment. Silodo$\sin$ has the highest selectivity for urinary $\alpha$-adrenergic receptors with an $\alpha 1 \mathrm{~A}: \alpha 1 \mathrm{~B}$ affinity ratio of 162:1 ( $\alpha 1 \mathrm{~A}$ affinity $>$ $\alpha 1 \mathrm{D}>\alpha 1 \mathrm{~B})[32,33$ ], thus showing a more favorable cardiovascular tolerability, although at the price of a higher risk of sexual dysfunction [34]. Indeed, an incidence of $0.2-1.4 \%$ is reported for silodosin-related $\mathrm{OH}$, with no statistically significant differences versus placebo [35-37]. Tamsulosin also shows a high uroselectivity, with a 10-fold greater affinity for $\alpha 1 \mathrm{~A}$ - and $\alpha 1 \mathrm{D}$-receptors as compared with the $\alpha 1 \mathrm{~B}$ subtype [32]. Yet, a relevant incidence of $\mathrm{OH}$ has been reported (42.4 events/10000 person-years) [38]. OH risk is higher for alfuzosin, prazosin, terazosin, and doxazosin, which present the lowest uroselectivity. $\alpha$-Blockers-related $\mathrm{OH}$ may be more pronounced in older patients, as a result of an age-related increase in vascular $\alpha 1 \mathrm{~B}$ receptors [32, 39]. Moreover, their hypotensive effect may be potentiated by the concomitant administration of phosphodiesterase type 5 inhibitors, which may be associated with $\alpha$-blockers to enhance their efficacy on lower urinary tract symptoms [40, 41].

Given all of the above, $\alpha$-blockers should be avoided as a treatment for high BP in older hypertensive subjects, as the European guidelines on hypertension recommend [42]. As concerns their use in prostatic hyperplasia, $\alpha$-blockers should only be prescribed in the presence of bladder outflow obstruction and more selective molecules should be preferred, to minimize the risk of $\mathrm{OH}$. The orthostatic BP fall may be more severe after the first dose (first-dose phenomenon), so that bed-time administration is advisable.

\subsection{Nitrates}

Nitrates have vasodilating effects deriving from nitric oxide release and vascular smooth muscle relaxation. Vasodilation predominantly involves the venous district, thus decreasing venous return and potentially impairing orthostatic BP. Therefore, nitrates are commonly listed among $\mathrm{OH}$ risk factors [12, 43, 44]. Additionally, nitrates are known to increase the risk of hypotensive syncope and falls in older patients, regardless of drug dosage [16, 45]. Conversely, their use as symptomatic treatment of chronic angina pectoris is widespread, while they can be safely discontinued in $90 \%$ of cases [27]. As an alternative, different anti-ischemic drugs with no or limited impact on orthostatic BP can be considered if indicated, such as calcium channel blockers, ivabradine, or ranolazine. Nevertheless, Kamaruzzaman et al. [15] identified a trend 
towards a negative association between nitrates and $\mathrm{OH}$ in a community-based sample of women aged $60-80$ years (adjusted RR 0.72, 95\% CI 0.49-1.05), probably deriving from tolerance development during prolonged treatment. Additionally, absorption of transdermal nitrates may be reduced in older patients due to an age-related decrease in dermal vasculature, which may at least partly explain this result.

\section{$2.4 \beta$-Blockers}

Due to their negative inotropic and chronotropic effect, $\beta$-blockers may interfere with the compensatory responses to standing and predispose to an orthostatic BP fall. Additionally, the blockade of juxtaglomerular and presynaptic $\beta 1$-adrenergic receptors reduces renin-angiotensin system activity and sympathetic outflow, respectively, thus counteracting vasoconstriction.

Data from the Irish Longitudinal Study on Ageing (TILDA) demonstrate that monotherapy with $\beta$-blockers is associated with an increased risk of $\mathrm{OH}$ during all phases of standing (OR 2.05, 95\% CI 1.31-3.21 for initial $\mathrm{OH}$; OR 3.36, 95\% CI 1.87-6.03 for sustained hypotension) [18]. Similarly, an association between $\beta$-blockers and $\mathrm{OH}$ has also been described in nursing home residents [46] and in patients with chronic kidney disease [47]. A higher incidence of $\mathrm{OH}$ has been reported for mixed $\alpha$ and $\beta$-blockers (e.g., carvedilol), particularly after the first dose [48]. In view of the above described data, prescription of $\beta$-blockers should preferably be limited to patients with a specific indication (e.g., coronary artery disease, heart failure or atrial fibrillation), as the European guidelines on hypertension recommend [42]. Additionally, mixed $\alpha$ - and $\beta$-blockers should preferably be avoided in patients with $\mathrm{OH}$.

\subsection{Clonidine}

Clonidine is an $\alpha-2$ agonist stimulating the presynaptic receptors of the vasomotor center in the brain stem, which induces a decrease of sympathetic tone and norepinephrine plasma levels [49]. At present, the effects of clonidine on orthostatic BP have been poorly investigated [12]. As clonidine induces a reduction of sympathetic activity, it cannot be excluded that it may interfere with adrenergic compensatory responses to standing, thus favoring the development of $\mathrm{OH}$. Additionally, clonidine is more frequently prescribed in patients with resistant hypertension and polypharmacy, which already carry increased risk of $\mathrm{OH}$. Yet, according to some authors, clonidine only determines a baseline reduction in the sympathetic outflow, which does not interfere with compensatory reflex responses to standing [49]. Finally, a single study describes a protective effect of centrally acting antihypertensive medications, which is currently unexplained [50]. Data on the $\alpha 2$ agonist methyl-dopa are scarce, but no increase in the risk of $\mathrm{OH}$ has been reported [51].

\subsection{Calcium Channel Blockers}

Data on calcium channel blockers as a risk factor for $\mathrm{OH}$ are conflicting. While an increased risk is reported in some studies $[17,30,50]$, some others do not describe any association $[43,52,53]$ or rather suggest a protective effect [54]. In a study by Gaxatte et al. [50], patients with $\mathrm{OH}$ more frequently received calcium antagonists $(23 \%$ vs $16 \%, p=0.02$ ), which were significantly associated with an increased risk of impaired BP response to standing (OR $1.79,95 \%$ CI 1.16-2.76). Similar results are reported by Press et al. [30] (OR 1.66, 95\% CI 1.11-2.48). Conversely, calcium antagonists showed a protective effect against $\mathrm{OH}$ in older people from TILDA (OR 0.68, 95\% CI 0.49-0.94, $p<0.001$ ) [54]. The heterogeneity of this drug class may at least partly explain these inconsistent results. Indeed, dihydropyridine calcium channel blockers frequently induce a compensatory heart rate increase, which may counteract a BP fall after standing, thus suggesting a potential explanation for their neutral/protective effect. Conversely, nondihydropyridine calcium channel blockers have negative chronotropic and inotropic effects, which probably interfere with compensatory cardiac responses to standing [55]. Additionally, the bioavailability of diltiazem and verapamil may be increased in older adults due to an age-related reduction of the first pass liver effect [12]. In contrast, amlodipine and lacidipine seem to have better tolerability, which is probably attributable to a slow binding to calcium channels and a slower onset of vasodilation [56]. A low risk of $\mathrm{OH}$ is also reported for isradipine [12].

\subsection{ACE Inhibitors and Angiotensin II Receptor Blockers}

The chronic use of ACE inhibitors (ACE-I) and angiotensin II receptor blockers does not seem to be associated with $\mathrm{OH}$ $[18,46,47]$. Conversely, a protective effect is reported by some studies $[28,46]$, which may be attributed to improved vascular compliance and increased baroreceptor sensitivity deriving from the inhibition of the renin-angiotensin system [57-59]. Yet, the 'first-dose' phenomenon has to be mentioned, which more likely occurs in patients with increased renin-angiotensin activity. A vasodilation in capacitance vessels or a transient baroreceptors down-regulation may give a rationale for this phenomenon [60]. As concerns single molecules, data specifically referring to valsartan [61] and 
candesartan $(\mathrm{OH}$ incidence $0.2-0.8 \%)$ [62] do not report a clinically significant impact on orthostatic BP. Among ACEI, OH risk seems to be higher for enalapril [63] and captopril, while it is lower for perindopril (incidence of hypotension $42 \%$ vs $15 \%$ for captopril and perindopril, respectively) [64].

\section{Drugs Acting on Central Nervous System Predisposing to $\mathrm{OH}$}

\subsection{Antidepressants}

$\mathrm{OH}$ is the most common cardiovascular adverse effect of tricyclic antidepressants (TCA), occurring in $10-50 \%$ of treated patients $[12,30,50,65]$. Indeed, pharmacodynamics of TCA also include a vasodilating effect deriving from $\alpha$-adrenergic receptors blockade. Consistently, $\mathrm{OH}$ risk varies among single molecules according to their affinity for $\alpha$-receptors, being higher for amitriptyline and clomipramine and lower for nortriptyline [12].

Serotonin-selective reuptake inhibitors (SSRI) are reported to cause $\mathrm{OH}$ less frequently than TCA $[9,12]$ and hypotension is included among uncommon $(\geq 1 / 1000$ to $<1 / 100)$ or rare $(\geq 1 / 10000$ to $<1 / 1000)$ adverse effects [66]. However, increasing evidence suggests that orthostatic BP may be impaired in patients on SSRI therapy, too [17, 30, 67], with a 2-fold increase in the risk of OH (OR 2.09, 95\% CI 1.33-3.19 [30]; OR 2.11, 95\% CI 1.25-3.57 [67]). The causal pathway is not definite, and the association observed between antidepressant treatment and $\mathrm{OH}$ in cross-sectional studies may be partially confounded, as $\mathrm{OH}$ has been associated with depression risk in longitudinal studies, independently of antidepressant treatment [68]. Yet, a vasodilating effect has been described for fluoxetine, sertraline, and citalopram, which is probably mediated by inhibition of calcium channels and calcium-elicited vasoconstriction [69, 70]. Additionally, a slight reduction in heart rate is reported for fluoxetine, citalopram, and paroxetine, which may contribute to $\mathrm{OH}$ [71]. A role of serotonin in central regulation of BP has also been hypothesized, as both serotonin and its precursor 5-hydroxytryptophan significantly lower BP in rats and the hypotensive effect is reduced by serotonin antagonists and enhanced by fluoxetine [72]. Finally, fluoxetine and paroxetine act as cytochrome CYP2D6 inhibitors, thus potentially reducing the metabolic rate of hypotensive drugs like nifedipine and $\beta$-blockers [73].

It is well known that serotonin-norepinephrine reuptake inhibitors (SNRI) may induce BP and heart rate increase. Nevertheless, a strong association between SNRI and OH has been described in a sample of older adults at high risk of falling (OR 5.37; CI 1.93-14.97) [50] and a mean decrease of standing BP values was observed after venlafaxine treatment in a small clinical study of older subjects, with $\mathrm{OH}$ developing in $29 \%$ of the sample [74]. Similarly, in a placebo-controlled trial, a small but significant drop of systolic $\mathrm{BP}$ was associated with duloxetine treatment, although no increase in incidence of $\mathrm{OH}$ was observed in the duloxetine group ( $\mathrm{OH}$ incidence vs placebo $15.6 \%$ vs $20.5 \%$ ) [75]. The hypotensive effects of SNRI may be explained by a dosedependent overstimulation of presynaptic $\alpha 2$-adrenergic receptors, resulting in reduced noradrenaline outflow [76], although underlying mechanisms have been poorly investigated to date. Duloxetine is included among cytochrome CYP2D6 inhibitors [73] and may thus enhance the hypotensive effects of some medications.

Trazodone is a multifunctional drug that also determines inhibition of $\alpha$-adrenergic receptors [77]. OH is reported in $1-7 \%$ of patients, thus representing the most common cardiovascular adverse effect $[17,78]$. Trazodone-related hypotension more likely occurs in patients with advanced age or cardiac diseases. It is usually transient and related to plasma drug concentration, so that $\mathrm{OH}$ risk is expected to be lower when low doses or prolonged-release formulations are prescribed [79].

\subsection{Benzodiazepines}

Evidence on the hemodynamic effects of benzodiazepines (BDZs) is mainly limited to intensive care settings, referring to intravenous BDZ administration in the context of sedation or anesthesia [80-82]. However, in a recent study, BDZ users had lower systolic BP values than controls (149 vs $161 \mathrm{mmHg} ; p<0.05$ ) [83]. Additionally, BDZs were shown to significantly impact on the orthostatic BP response (Fig. 2), being independently associated with a greater BP drop at 10 seconds after standing [83]. Similarly, BDZs were found to induce orthostatic hypotension in deconditioned subjects [84], but the underlying mechanism is still debated. The presence of BDZ receptors has been demonstrated in the heart [85] and a negative inotropic effect has been described, both in animals [85] and humans [86, 87]. Moreover, previous data suggest that BDZs reduce the sympathetic tone [81] and the norepinephrine response to posture changes [88]. Finally, orthostatic BP impairment may develop as a consequence of BDZ-induced myorelaxation, which increases venous capacitance and lower-body venous pooling [83, 84]. The BDZ receptor agonist zolpidem does not exhibit myorelaxant effects and does not seem to be associated with $\mathrm{OH}[84]$.

\subsection{Antipsychotics}

$\mathrm{OH}$ develops in up to $40 \%$ of patients taking antipsychotics [89], with a higher incidence at advanced age. Once again, $\mathrm{OH}$ is mediated by inhibition of $\alpha 1$-adrenergic receptors 
Fig. 2 Effects of benzodiazepines on orthostatic blood pressure. Reproduced with permission (Rivasi et al. 2019, [83], Copyright Elsevier). BDZs benzodiazepines

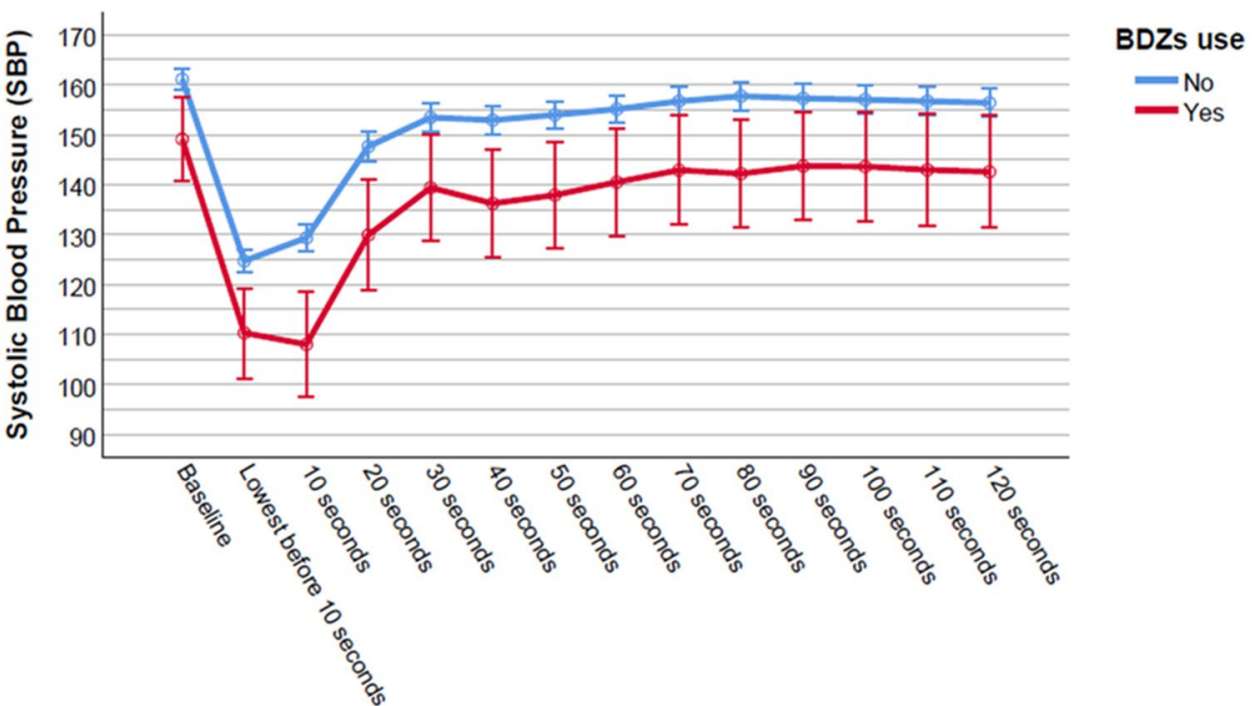

[77] and the risk profile of single molecules varies according to their binding affinity [90]. Clozapine and quetiapine show the highest risk, with an $\mathrm{OH}$ incidence of $24 \%$ and $27 \%$, respectively [91]; a similar incidence is reported for chlorpromazine. Conversely, $\mathrm{OH}$ risk is lowest for haloperidol and olanzapine $[12,90]$. Hypotensive effects are doserelated and the lowest effective dose should be prescribed, to minimize the risk of $\mathrm{OH}$ [91]. $\mathrm{OH}$ may be transient since tolerance usually develops within a few weeks [12]; however, an impairment of orthostatic BP response has been observed in chronic users as well [92].

\subsection{Other Psychoactive Drugs}

Dopaminergic drugs may cause $\mathrm{OH}$ through the activation of dopamine receptors, leading to cutaneous, mesenteric, and renal vasodilation [93]. Therefore, levodopa significantly contributes to $\mathrm{OH}$ associated with Parkinson disease, irrespective of the presence of autonomic dysfunction. Among antiparkinsonian drugs, the monoamine oxidaseB (MAO-B) inhibitor, selegiline, has also been reported to cause $\mathrm{OH}$, even if the underlying mechanism is still unclear $[94,95]$. Selegiline metabolites amphetamines and methamphetamines may be involved, causing a reduction in cardiac output and central norepinephrine levels [94]. Unlike selegiline, rasagiline, a second-generation MAO-B inhibitor, is less likely to cause hypotensive effects [96]. Conversely, treatment with entacapone, a catechol- $O$-methyltransferase (COMT) inhibitor, seems to have protective effects against $\mathrm{OH}$, which are probably attributable to a reduced peripheral catabolism of catecholamines [97].

Opioids can decrease cardiac output when administered with BDZs or as part of anesthesia. Additionally, acute administration of opioids can lead to vasodilation and decreased sympathetic outflow. Moreover, the chronic use of opioids, including morphine, hydrocodone, hydromorphone, and meperidine can also induce histamine release, resulting in a significant decrease of vascular resistance and BP [13, 77]. Opioid treatment may thus favor $\mathrm{OH}$, particularly in patients with reduced cardiac function or taking hypotensive medications [13].

The $N$-methyl-D-aspartate (NMDA) antagonist, memantine, was found to be significantly associated with $\mathrm{OH}$ in geriatric ward patients [31]. Additionally, a 2-fold increased risk of reflex syncope has been reported (RR 2.11) [98]. As memantine is typically prescribed to patients with moderate-to-severe dementia, a condition typically associated with $\mathrm{OH}$, and the cited studies did not adjust for cognitive impairment severity, it is likely that a great extent of confounding is presented in the cited associations. Yet, a sympatholytic action of memantine may be involved, since NMDA receptors are also located in the cardiovascular system and mediate an increase in adrenergic activity [99]. French pharmacovigilance data are consistent with this hypothesis, reporting bradycardia as the most common cardiovascular adverse effect of memantine [100]. Similarly, a non-competitive NMDA receptor antagonist was found to induce bradycardia in pigs [101].

\section{Drug Treatment of $\mathrm{OH}$}

In addition to a review of medical therapy, the first-line strategy for the management of $\mathrm{OH}$ is represented by non-pharmacological interventions including hydration, avoidance of precipitating factors for low BP, application of compression stockings or abdominal binders, and physical conditioning [2]. Pharmacological treatment options are limited, but can be considered in patients with more severe forms of $\mathrm{OH}$ if symptoms persist in spite of non-pharmacological strategies, provided that drug treatment is added to, rather than 
replacing lifestyle measures [102-104]. Evidence supporting the efficacy of drug treatment for $\mathrm{OH}$ is scarce and mainly refers to patients with primary forms of autonomic failure, who actually represent a minority of $\mathrm{OH}$ subjects in routine clinical practice [102]. Among the available drug therapies, only droxidopa and midodrine have shown positive results in randomized controlled clinical trials and they represent the sole Food and Drug Administration-approved molecules for $\mathrm{OH}$ treatment [102].

It is important to consider that pharmacological strategies should not aim to achieve pre-defined BP values, but should rather target the improvement of patients' symptoms and quality of life [102]. Consequently, drug treatment of $\mathrm{OH}$ should be managed on an individual basis and progressively titrated to reach to lowest effective dose. In patients with symptoms refractory to treatment, combination therapy can be considered [104, 105].

\subsection{Midodrine}

Midodrine is an $\alpha 1$-agonist that acts through an increase in peripheral vascular resistance and the reduction of venous pooling in the splanchnic and leg vessels [106]. The use of midodrine in patients with neurogenic $\mathrm{OH}$ is supported by high quality of evidence [102]. Three randomized, doubleblind trials have demonstrated that midodrine $(2.5-30 \mathrm{mg} /$ day) has a greater pressor effect than placebo in patients with autonomic failure [107-109], while Fouad-Tarazi et al. [110] have showed that midodrine significantly improves standing $\mathrm{BP}$ and orthostatic tolerance in these patients.

Midodrine is characterized by a short half-life, which requires frequent dosing and may limit long-term compliance [107]. Yet, this allows for its use in patients with supine hypertension (i.e., systolic BP values $\geq 140 \mathrm{mmHg}$ and/or diastolic BP values $\geq 90 \mathrm{mmHg}$ in the supine position [111]), as daytime administration does not significantly increase the risk of high nocturnal BP. Midodrine is usually administered at an initial dose of $2.5-5 \mathrm{mg}$ twice to three times a day and then titrated, as tolerated, up to a maximum dose of $30 \mathrm{mg} / \mathrm{day}$ [112]. The most common adverse effects are pilomotor reactions, chills, and urinary retention, which requires special caution in older males $[108,109]$. Dosing should not be administered within 4 hours of bedtime to avoid supine hypertension.

\subsection{Droxidopa}

Droxidopa is a synthetic norepinephrine prodrug that is converted into norepinephrine by aromatic L-amino acid (DOPA) decarboxylase in both central nervous system and peripheral tissues, thus promoting vasoconstriction [102]. The efficacy of droxidopa in neurogenic $\mathrm{OH}$ has been investigated in five randomized placebo-controlled trials. Most of these showed beneficial effects on supine and standing BP and orthostatic tolerance [113-116], while two studies failed to demonstrate a significant improvement in patients' symptoms $[117,118]$. Several additional small-sized studies and case reports further support the use of droxidopa in neurogenic $\mathrm{OH}$ [119-122], and a review by Keating confirms that droxidopa is associated with an improvement in orthostatic tolerance, a reduction in symptom impact on daily activities and an increase in standing systolic BP of approximately $10 \mathrm{mmHg}$ [123]. However, the long-term efficacy of droxidopa remains to be confirmed and quality of evidence is considered to be moderate $[102,123]$.

Droxidopa is usually administered at an initial dose of $100 \mathrm{mg}$ three times per day and is then titrated until symptom reduction occurs to a maximum dose of $600 \mathrm{mg}$ three times per day [112]. Droxidopa has a favorable safety profile, showing an incidence of adverse events comparable to placebo and a relatively low reported incidence of adverse events related to supine hypertension [102]. However, it is not recommended to be taken within $3-5 \mathrm{~h}$ of bedtime to reduce the risk of high nocturnal BP. Other typical adverse effects include headache, dizziness, and nausea, which are often dose dependent [112]. Droxidopa may exacerbate symptoms in patients with heart failure, arrhythmias, and ischemic heart disease. Caution is also recommended in patients receiving other medications increasing norepinephrine levels (e.g., $\alpha 1$-agonists and $\alpha 2$-agonists) [124].

\subsection{Fludrocortisone}

Fludrocortisone is a synthetic mineralocorticoid, which expands intravascular volume by increasing renal water and sodium reabsorption [102]. Increase in plasma volume is usually transient, due to a mineralocorticoid escape [125]. The long-term effects of fludrocortisone are mainly attributed to an increase in vascular resistance, which is supposed to derive from enhanced sensitivity of $\alpha$-adrenoreceptors and potentiation of the pressor effect of norepinephrine and angiotensin II [105, 124].

Fludrocortisone is commonly prescribed in patients with neurogenic $\mathrm{OH}$, as it has been shown to improve standing and supine BP in small-sized, open-label studies involving patients with diabetes and Parkinson disease [126-130]. Yet, evidence supporting the use of fludrocortisone for $\mathrm{OH}$ therapy is considered to be weak [102].

Fludrocortisone is usually administered at the initial dose of $0.1-0.2 \mathrm{mg} /$ day and then gradually increased up to $0.3-0.4 \mathrm{mg} /$ day [112]. Common side effects include hypokalemia, supine hypertension, volume overload, and headaches. Given the risk of fluid overload, heart failure and renal impairment are relative contraindications to the use of fludrocortisone [112]. 


\subsection{Pyridostigmine}

Pyridostigmine is a cholinesterase inhibitor that prevents the metabolism of acetylcholine, thus potentiating cholinergic neurotransmission in sympathetic ganglia [102]. Consequently, pyridostigmine leads to an increase in BP that is especially to be expected when sympathetic tone is increased (i.e., on standing), while it has limited effects on supine BP. For the same reason, it is likely more useful in less severe patients with residual sympathetic function [131-133].

Evidence supporting the use of pyridostigmine is weak [102] and side effects associated with cholinergic stimulation may occur, such as abdominal cramps, diarrhea, sialorrhea, excessive sweating, urinary incontinence, and increased bronchial secretions/bronchospasm [102, 124]. However, some of these may be beneficial in patients with neurogenic $\mathrm{OH}$ and autonomic failure presenting with constipation and anhidrosis. Pyridostigmine should be used with caution in patients with bradycardia, glaucoma, renal impairment, or respiratory diseases, such as asthma or chronic obstructive pulmonary disease [124]. Typical dosing is 30-60 mg once to three times per day [112].

\subsection{Emerging Treatment Options}

\subsubsection{Octreotide}

Octreotide is a somatostatin analog that reduces the release of gastrointestinal vasodilatory peptides and the subsequent postprandial splanchnic hyperemia, thus counteracting venous pooling in the splanchnic district [124]. Alam et al. analyzed the effects octreotide on 24-hour ambulatory BP in 18 subjects with primary autonomic failure and reported an increase in systolic and diastolic $\mathrm{BP}(+5$ and $+2 \mathrm{mmHg}$, respectively) and a reduction in postural and post-prandial hypotension and related symptoms. Additionally, a decrease in nocturnal BP was observed [134]. However, quality of evidence showing the efficacy of octreotide is considered to be low [102]. Octreotide is administered through subcutaneous injections at a dose of 12.5-25 $\mu \mathrm{g}$ [124]. The development of gallstones or biliary sludging, abdominal pain and nausea, dysglycemia, and hypothyroidism may occur as adverse effects. For this reason, octreotide is not recommended in patients with diabetes mellitus, especially in case of concomitant gastroparesis [124].

\subsubsection{Atomoxetine}

Pharmacologic inhibition of the norepinephrine transporter with atomoxetine was found to improve orthostatic tolerance in patients with autonomic failure, thus representing a promising treatment option [135]. Yet, the potential use of atomoxetine is limited by low quality of evidence and safety concerns [102]. Attention should be given to potential adverse effects including depression, aggressive behavior, priapism, and urination retention. Additionally, hepatotoxicity can occur, thus making liver function monitoring advisable and dose adjustment necessary in patients with hepatic impairment [124]. Finally, death, stroke, and myocardial infarction have been described in patients with severe structural cardiac diseases or heart rate abnormalities receiving atomoxetine [124].

\subsubsection{Desmopressin}

The vasopressin analog desmopressin acts as a volume expander, increasing water reabsorption. Desmopressin has been shown to reduce nocturnal polyuria and the related morning fall in orthostatic BP in patients with autonomic failure [135]. However, its efficacy remains uncertain [102]. Additionally, careful treatment monitoring is required to avoid water overload and hyponatremia, which seem to be less likely with low-dose intranasal formulations [135].

\subsubsection{Erythropoietin}

As anemia predisposes to an impairment of the BP response to standing, recombinant erythropoietin may play a role in the pharmacological approach to $\mathrm{OH}$ [102]. Data from a small sample of patients with neurogenic $\mathrm{OH}$ indicate that erythropoietin may increase orthostatic systolic and diastolic BP and improve orthostatic symptoms, with no relevant changes in supine BP [136]. Erythropoietin-mediated BP increase is likely related to multiple mechanisms involving an increase in red-cell volume, nitric oxide resistance, and endothelin-1 production [136, 137]. However, its use is limited by the risk of cardiovascular events and mortality [137].

\section{Conclusion}

Medical therapy is one of the most common causes of $\mathrm{OH}$. Medications at highest risk of $\mathrm{OH}$ include cardiovascular drugs (e.g., diuretics, nitrates, $\beta$ - and $\alpha$-receptor blockers), and non-cardiovascular drugs (e.g., antidepressants, antipsychotics, trazodone, and BDZs). Table 1 provides a risk stratification for commonly used medications. There is virtually no head-to-head comparisons of different drug classes and the available literature referring to drug-related $\mathrm{OH}$ mainly includes small studies with a cross-sectional design, with most providing conflicting results. Therefore, the risk stratification provided in Table 1 may be questionable, somewhat arbitrary, and not supported by strong evidence but mostly by clinical experience and available scientific data. Nevertheless, since our paper aims to be a 
Table 1 Cardiovascular (a) and psychoactive drugs (b) predisposing to drug-related orthostatic hypotension: overview of hypotensive mechanisms, risk profiles and therapy optimization strategies

Drug class $\quad$ Main mechanism responsible for drug-related $\mathrm{OH}$ Risk profile Practical advice for drug review in patients with
$\mathrm{OH}$

\section{A. Cardiovascular drugs \\ $\alpha$-Blockers}

Reduced vascular resistance [29-31]

\section{$+++$}

Avoid as a treatment for hypertension in older patients [32, 39, 42]

Prefer uroselective molecules (e.g., silodosin) in patients with bladder outflow obstruction [35-37]

Preferably administer at bedtime

\begin{tabular}{|c|c|c|c|}
\hline Nitrates & Vasodilation & +++ & $\begin{array}{l}\text { Prescribe the lowest effective dose for symptom } \\
\text { (angina) control and attempt discontinuation if } \\
\text { patient is asymptomatic [27] }\end{array}$ \\
\hline Diuretics & Volume depletion & ++ & $\begin{array}{l}\text { Prescribe the lowest effective dose and consider } \\
\text { withdrawal if fluid overload is absent and } \mathrm{OH} \text { is } \\
\text { clinically significant [27] } \\
\text { Avoid loop diuretics (e.g., furosemide) as a treat- } \\
\text { ment for hypertension if high risk of volume } \\
\text { depletion is present, unless specifically required } \\
\text { (e.g., renal dysfunction) [26] }\end{array}$ \\
\hline$\beta$-Blockers & $\begin{array}{l}\text { Interference with compensatory reflex responses } \\
\text { to standing (e.g., sympathetic-mediated vaso- } \\
\text { constriction, increased heart rate response and } \\
\text { inotropism) [77] }\end{array}$ & ++ & $\begin{array}{l}\text { Consider withdrawal in presence of } \mathrm{OH} \text {, unless } \\
\text { specifically indicated (e.g., heart failure) [42] } \\
\text { Preferably avoid mixed } \alpha \text { - and } \beta \text {-blockers (e.g., } \\
\text { carvedilol) in patients with } \mathrm{OH}[48]\end{array}$ \\
\hline Calcium channel blockers & $\begin{array}{l}\text { Reduced heart rate response and inotropism (non- } \\
\text { dihydropyridines), vasodilation [77] }\end{array}$ & ++ & $\begin{array}{l}\text { Prefer dihydropyridine calcium antagonist (e.g., } \\
\text { amlodipine or lacidipine), unless a negative } \\
\text { chronotropic effect is required [56] }\end{array}$ \\
\hline Clonidine & Reduced sympathetic tone [49] & + & $\begin{array}{l}\text { OH risk debated }[12,49,50] \text {, preferably use as a } \\
\text { second-line antihypertensive therapy }\end{array}$ \\
\hline $\begin{array}{l}\text { ACE-inhibitors, } \\
\text { Angiotensin II receptor } \\
\text { blockers }\end{array}$ & $\begin{array}{l}\text { Low risk, possible protective effect }[18,28,46 \text {, } \\
\text { 47] }\end{array}$ & + & $\begin{array}{l}\text { Preferably use as a first line antihypertensive } \\
\text { therapy } \\
\text { First-dose phenomenon to be considered [60-64] }\end{array}$ \\
\hline \multicolumn{4}{|l|}{ B. Psychoactive drugs } \\
\hline Levodopa & Vasodilation [93] & +++ & Prescribe the lowest effective dose \\
\hline Antipsychotics & Reduced vascular resistance [77] & +++ & $\begin{array}{l}\text { Start with a low dose } \\
\text { Prescribe at the lowest effective dose } \\
\text { Highest risk for clozapine, quetiapine, and chlor- } \\
\text { promazine [91] }\end{array}$ \\
\hline Tricyclic antidepressants & Reduced vascular resistance [12] & ++ & $\begin{array}{l}\text { Prefer SSRI or SNRI antidepressants (e.g., sertra- } \\
\text { line, paroxetine, citalopram, venlafaxine) [12] }\end{array}$ \\
\hline Benzodiazepines & $\begin{array}{l}\text { Unclear (myorelaxation, reduced sympathetic } \\
\text { tone) [83-87] }\end{array}$ & ++ & $\begin{array}{l}\text { Avoid in older people [83] } \\
\text { Prescribe the lowest effective dose }\end{array}$ \\
\hline Trazodone & Reduced vascular resistance [77] & ++ & $\begin{array}{l}\text { Start with a low dose }[79] \\
\text { Prefer prolonged-release formulations or frac- } \\
\text { tioned doses }[69,70,72]\end{array}$ \\
\hline Opioids & Reduced vascular resistance $[13,77]$ & ++ & $\begin{array}{l}\text { Prescribe the lowest effective dose } \\
\text { Caution in patients with cardiac dysfunction and/ } \\
\text { or hypotensive drugs [13] }\end{array}$ \\
\hline SSRI, SNRI & $\begin{array}{l}\text { Unclear (inhibition of calcium channels, central } \\
\text { serotonin agonism, overstimulation of presyn- } \\
\text { aptic } \alpha 2 \text {-adrenergic receptors) }[73,77]\end{array}$ & + & $\begin{array}{l}\text { OH possible but less common than with tricyclic } \\
\text { antidepressants }[9,12,66]\end{array}$ \\
\hline Memantine & Unclear [98-101] & + & $\begin{array}{l}\text { OH risk potentially related to both therapy and } \\
\text { dementia [98-100] }\end{array}$ \\
\hline
\end{tabular}

+++ , Highest risk of drug-related $\mathrm{OH} ;++$, intermediate risk of drug-related $\mathrm{OH} ;+$, lowest risk of drug-related $\mathrm{OH}$

$O H$ orthostatic hypotension, SNRI serotonin-norepinephrine reuptake inhibitors, SSRI serotonin-selective reuptake inhibitors 
practical tool for therapy optimization in patients with $\mathrm{OH}$, this risk stratification may be useful to increase awareness on potential causative drugs and to identify priorities in the context of medication review. Withdrawal or reduction of potentially causative medications may reduce drugrelated $\mathrm{OH}$ and represents a first-line treatment strategy in patients with orthostatic BP impairment.

Specific drug treatment for $\mathrm{OH}$ may be considered if symptoms persist despite non-pharmacological measures. Health care professionals should thus be educated to optimize medical therapy in subjects with $\mathrm{OH}$, in the context of a comprehensive assessment of clinical status and preferences of individual patients.

\section{Declarations}

Funding No external funding was used in the preparation of this manuscript. Open access funding provided by Università degli Studi di Firenze within the CRUI-CARE Agreement.

Conflicts of interest/competing interests Giulia Rivasi, Martina Rafanelli, Enrico Mossello, Michele Brignole, and Andrea Ungar declare that they have no potential conflicts of interest that might be relevant to the contents of this manuscript.

Compliance with ethical standards Not applicable.

Consent to participate Not applicable.

Consent for publication Not applicable.

Availability of data and material Not applicable.

Code availability Not applicable.

Author contributions Study conception and design: Rivasi; literature search, draft and/or critical revision of the work and approval of final manuscript: all authors.

Open Access This article is licensed under a Creative Commons Attribution-NonCommercial 4.0 International License, which permits any non-commercial use, sharing, adaptation, distribution and reproduction in any medium or format, as long as you give appropriate credit to the original author(s) and the source, provide a link to the Creative Commons licence, and indicate if changes were made. The images or other third party material in this article are included in the article's Creative Commons licence, unless indicated otherwise in a credit line to the material. If material is not included in the article's Creative Commons licence and your intended use is not permitted by statutory regulation or exceeds the permitted use, you will need to obtain permission directly from the copyright holder. To view a copy of this licence, visit http://creativecommons.org/licenses/by-nc/4.0/.

\section{References}

1. Freeman R, Wieling W, Axelrod FB, et al. Consensus statement on the definition of orthostatic hypotension, neurally mediated syncope and the postural tachycardia syndrome. Auton Neurosci. 2011;161:46-8.
2. Brignole M, Moya A, de Lange FJ, Deharo JC, Elliott PM, Fanciulli A, et al. Practical Instructions for the 2018 ESC Guidelines for the diagnosis and management of syncope. Eur Heart $\mathrm{J}$. 2018;39(21):e43-80.

3. Ceccofiglio A, Mussi C, Rafanelli M, et al. Increasing prevalence of orthostatic hypotension as a cause of syncope with advancing age and multimorbidity. J Am Med Dir Assoc. 2019;20:586-8.

4. Fedorowski A, Stavenow L, Hedblad B, et al. Orthostatic hypotension predicts all-cause mortality and coronary events in middle-aged individuals (The Malmo Preventive Project). Eur Heart J. 2010;31:85-91.

5. Wolters FJ, Mattace-Raso FU, Koudstaal PJ, Heart Brain Connection Collaborative Research Group, et al. Orthostatic hypotension and the long-term risk of dementia: a population-based study. PLoS Med. 2016;13:e002143.

6. Mossello E, Marchionni N. Vascular risk factors and cognitive function. the effect of aging process. In: Govoni S, et al., editors. Brain and heart dynamics. Switzerland: Springer Nature; 2020.

7. Smith JJ, Porth CM, Erickson M. Hemodynamic response to the upright posture. J Clin Pharmacol. 1994;34(5):375-86.

8. Shibao C, Raj SR, Gamboa A, Diedrich A, Choi L, Black BK, et al. Norepinephrine transporter blockade with atomoxetine induces hypertension in patients with impaired autonomic function. Hypertension. 2007;50(1):47-53.

9. Montastruc JL, Laborie I, Bagheri H, Senard JM. Drug-induced orthostatic hypotension. A five-year experience in a regional pharmacovigilance centre in France. Clin Drug Investig. 1997; $14: 61$.

10. ElDesoky ES. Pharmacokinetic-pharmacodynamic crisis in the elderly. Am J Ther. 2007;14:488-98.

11. Moonen JE, Foster-Dingley JC, de Ruijter W, van der Grond $\mathrm{J}$, de Craen AJ, van der Mast RC. Effect of discontinuation of antihypertensive medication on orthostatic hypotension in older persons with mild cognitive impairment: the DANTE Study Leiden. Age Ageing. 2016;45(2):249-55.

12. Verhaeverbeke I, Mets T. Drug-induced orthostatic hypotension in the elderly: avoiding its onset. Drug Saf. 1997;17(2):105-18.

13. Chen A, Ashburn MA. Cardiac effects of opioid therapy. Pain Med. 2015;16(Suppl 1):S27-31.

14. Fedorowski A, Burri P, Juul-Möller S, Melander O. A dedicated investigation unit improves management of syncopal attacks (Syncope Study of Unselected Population in Malmo-SYSTEMA I). Europace. 2010;12(9):1322-8.

15. Kamaruzzaman S, Watt H, Carson C, Ebrahim S. The association between orthostatic hypotension and medication use in the British Women's Heart and Health Study. Age Ageing. 2010;39(1):51-6.

16. Mussi C, Ungar A, Salvioli G, Menozzi C, Bartoletti A, Giada F, Evaluation of Guidelines in Syncope Study 2 Group, et al. Orthostatic hypotension as cause of syncope in patients older than 65 years admitted to emergency departments for transient loss of consciousness. J Gerontol A Biol Sci Med Sci. 2009;64(7):801-6.

17. Poon IO, Braun U. High prevalence of orthostatic hypotension and its correlation with potentially causative medications among elderly veterans. J Clin Pharm Ther. 2005;30:173-8.

18. Canney M, O'Connell MD, Murphy CM, O'Leary N, Little MA, O'Seaghdha CM, Kenny RA. Single agent antihypertensive therapy and orthostatic blood pressure behaviour in older adults using beat-to-beat measurements: the irish longitudinal study on ageing. PLoS One. 2016;11(1):e0146156.

19. Raiha I, Luutonen S, Piha J, Seppanen A, Toikka T, et al. Prevalence, predisposing factors, and prognostic importance of postural hypotension. Arch Intern Med. 1995;155:930-5.

20. Wu JS, Yang YC, Lu FH, Wu CH, Wang RH, et al. Populationbased study on the prevalence and risk factors of orthostatic 
hypotension in subjects with pre-diabetes and diabetes. Diabetes Care. 2009;32:69-74.

21. Rose KM, Tyroler HA, Nardo CJ, Arnett DK, Light KC, et al. Orthostatic hypotension and the incidence of coronary heart disease: the Atherosclerosis Risk in Communities study. Am J Hypertens. 2000;13:571-8.

22. Rose KM, Eigenbrodt ML, Biga RL, Couper DJ, Light KC, et al. Orthostatic hypotension predicts mortality in middle-aged adults: the Atherosclerosis Risk In Communities (ARIC) Study. Circulation. 2006;114:630-6.

23. Hiitola P, Enlund H, Kettunen R, Sulkava R, Hartikainen S. Postural changes in blood pressure and the prevalence of orthostatic hypotension among home-dwelling elderly aged 75 years or older. J Hum Hypertens. 2009;23(1):33-9.

24. Cox JR, Admani AK, Agarwal ML, et al. Postural hypotension: body fluid compartments and electrolytes. Age Ageing. 1973;2(2):112-20.

25. Shannon RP, Wei JY, Rosa RM, Epstein FH, Rowe JW. The effect of age and sodium depletion on cardiovascular response to orthostasis. Hypertension. 1986;8(5):438-43.

26. Sica DA, Carter B, Cushman W, Hamm L. Thiazide and loop diuretics. J Clin Hypertens (Greenwich). 2011;13(9):639-43.

27. Dills H, Shah K, Messinger-Rapport B, Bradford K, Syed Q. Deprescribing medications for chronic diseases management in primary care settings: a systematic review of randomized controlled trials. J Am Med Dir Assoc. 2018;19(11):923-35.

28. Fedorowski A, Burri P, Melander O. Orthostatic hypotension in genetically related hypertensive and normotensive individuals. J Hypertens. 2009;27(5):976-82.

29. Wong AK, Lord SR, Sturnieks DL, Delbaere K, Trollor JN, Close JC. Angiotensin system-blocking medications are associated with fewer falls over 12 months in community-dwelling older people. J Am Geriatr Soc. 2013;61(5):776-81.

30. Press Y, Punchik B, Freud T. Orthostatic hypotension and drug therapy in patients at an outpatient comprehensive geriatric assessment unit. J Hypertens. 2016;34(2):351-8.

31. Wojszel ZB, Kasiukiewicz A, Magnuszewski L. Health and functional determinants of orthostatic hypotension in geriatric ward patients: a retrospective cross sectional cohort study. J Nutr Health Aging. 2019;23(6):509-17.

32. Schwinn DA, Roehrborn CG. Alpha1-adrenoceptor subtypes and lower urinary tract symptoms. Int J Urol. 2008;15(3):193-9.

33. Tatemichi S, Kobayashi K, Maezawa A, Kobayashi M, Yamazaki Y, Shibata N. Alpha1-adrenoceptor subtype selectivity and organ specificity of silodosin (KMD-3213). Yakugaku Zasshi. 2006;126:209-16.

34. Jung JH, Kim J, MacDonald R, Reddy B, Kim MH, Dahm P. Silodosin for the treatment of lower urinary tract symptoms in men with benign prostatic hyperplasia. Cochrane Database Syst Rev. 2017;11(11):CD012615.

35. Montorsi F. Profile of silodosin. Eur Urol Suppl. 2010;9:491-5.

36. Chapple CR, Montorsi F, Tammela TL, Wirth M, Koldewijn E, Fernández Fernández E, European Silodosin Study Group. Silodosin therapy for lower urinary tract symptoms in men with suspected benign prostatic hyperplasia: results of an international, randomized, double-blind, placebo- and active-controlled clinical trial performed in Europe. Eur Urol. 2011;59(3):342-52.

37. Fonseca J, da Silva MC. The diagnosis and treatment of lower urinary tract symptoms due to benign prostatic hyperplasia with $\alpha$-blockers: focus on silodosin. Clin Drug Investig. 2015;35(1):7-18.

38. Bird ST, Delaney JA, Brophy JM, Etminan M, Skeldon SC, Hartzema AG. Tamsulosin treatment for benign prostatic hyperplasia and risk of severe hypotension in men aged 40-85 years in the United States: risk window analyses using between and within patient methodology. BMJ. 2013;347:f6320.
39. Rudner XL, Berkowitz DE, Booth JV, Funk BL, Cozart KL, D'Amico EB, El-Moalem H, Page SO, Richardson CD, Winters B, Marucci L, Schwinn DA. Subtype specific regulation of human vascular alpha(1)-adrenergic receptors by vessel bed and age. Circulation. 1999;100(23):2336-43.

40. Hatzimouratidis K, Amar E, Eardley I, Giuliano F, Hatzichristou D, Montorsi F, Vardi Y, Wespes E, European Association of Urology. Guidelines on male sexual dysfunction: erectile dysfunction and premature ejaculation. Eur Urol. 2010;57(5):804-14.

41. Gacci M, Corona G, Salvi M, Vignozzi L, McVary KT, Kaplan SA, Roehrborn CG, Serni S, Mirone V, Carini M, Maggi M. A systematic review and meta-analysis on the use of phosphodiesterase 5 inhibitors alone or in combination with $\alpha$-blockers for lower urinary tract symptoms due to benign prostatic hyperplasia. Eur Urol. 2012;61(5):994-1003.

42. Williams B, Mancia G, Spiering W, Agabiti Rosei E, Azizi M, Burnier M, Clement DL, Coca A, de Simone G, Dominiczak A, Kahan T, Mahfoud F, Redon J, Ruilope L, Zanchetti A, Kerins M, Kjeldsen SE, Kreutz R, Laurent S, Lip GYH, McManus R, Narkiewicz K, Ruschitzka F, Schmieder RE, Shlyakhto E, Tsioufis C, Aboyans V, Desormais I, ESC Scientific Document Group. 2018 ESC/ESH Guidelines for the management of arterial hypertension. Eur Heart J. 2018;39(33):3021-104.

43. Ylitalo R, Kähönen M, Nieminen T, Kööbi T, Ylitalo P, Turjanmaa V. Effects of a mononitrate, a beta1-blocker and a dihydropyridine calcium channel blocker on cardiovascular responsiveness to passive orthostasis: a placebo-controlled double-blind study in normotensive volunteers. Arzneimittelforschung. 2005;55(3):160-6.

44. Milazzo V, Stefano CD, Servo S, Crudo V, Fulcheri C, Maule $\mathrm{S}$, et al. Drugs and orthostatic hypotension: evidence from literature. J Hypertens. 2012;1:104. https://doi.org/10.4172/21671095.1000104.

45. Testa G, Ceccofiglio A, Mussi C, Bellelli G, Nicosia F, Bo M, Riccio D, Curcio F, Martone AM, Noro G, Landi F, Ungar A, Abete P. Hypotensive drugs and syncope due to orthostatic hypotension in older adults with dementia (syncope and dementia study). J Am Geriatr Soc. 2018;66(8):1532-7.

46. Valbusa F, Labat C, Salvi P, Vivian ME, Hanon O, Benetos A, PARTAGE investigators. Orthostatic hypotension in very old individuals living in nursing homes: the PARTAGE study. $\mathbf{J}$ Hypertens. 2012;30(1):53-60.

47. Juraschek SP, Appel LJ, Miller ER, Mukamal KJ, Lipsitz LA. Hypertension treatment effects on orthostatic hypotension and its relationship with cardiovascular disease. Hypertension. 2018;72(4):986-93.

48. Krum H, Conway EL, Broadbear JH, Howes LG, Louis WJ. Postural hypotension in elderly patients given carvedilol. BMJ. 1994;309(6957):775-6.

49. Oster JR, Epstein M. Use of centrally acting sympatholytic agents in the management of hypertension. Arch Intern Med. 1991;151(8):1638-44.

50. Gaxatte C, Faraj E, Lathuillerie O, Salleron J, Deramecourt V, Pardessus V, Destailleur MH, Boulanger E, Puisieux F. Alcohol and psychotropic drugs: risk factors for orthostatic hypotension in elderly fallers. J Hum Hypertens. 2017;31(4):299-304.

51. Amery AK, Bossaert H, Fagard RH, et al. Clonidine versus methyldopa: a double blind cross-over study comparing side effects of clonidine and methyldopa administered together with chlorthalidone at a dosage producing the same blood pressure lowering effect. Acta Cardiol. 1972;21(1):82-99.

52. Forette F, McClaran J, Hervy MP, Bouchacourt P, Henry JF. Nicardipine in elderly patients with hypertension: a review of experience in France. Am Heart J. 1989;117(1):256-61.

53. Kennelly SP, Abdullah L, Paris D, Parish J, Mathura V, Mullan M, Crawford F, Lawlor BA, Kenny RA. Demonstration of 
safety in Alzheimer's patients for intervention with an antihypertensive drug Nilvadipine: results from a 6-week open label study. Int J Geriatr Psychiatry. 2011;26(10):1038-45.

54. Romero-Ortuno R, O'Connell MD, Finucane C, Soraghan C, Fan CW, Kenny RA. Insights into the clinical management of the syndrome of supine hypertension-orthostatic hypotension (SH-OH): the Irish Longitudinal Study on Ageing (TILDA). BMC Geriatr. 2013;15(13):73.

55. Di Stefano C, Milazzo V, Totaro S, Sobrero G, Ravera A, Milan A, Maule S, Veglio F. Orthostatic hypotension in a cohort of hypertensive patients referring to a hypertension clinic. J Hum Hypertens. 2015;29(10):599-603.

56. Opie LH. Profiles of calcium antagonists in cardiovascular disease with special reference to second-generation agents and amlodipine. Postgrad Med J. 1991;67(Suppl 5):S2-8.

57. Egan BM, Fleissner MJ, Stepniakowski K, Neahring JM, Sagar $\mathrm{KB}$, Ebert TJ. Improved baroreflex sensitivity in elderly hypertensives on lisinopril is not explained by blood pressure reduction alone. J. Hypertens. 1993;11:1113-20.

58. Park JB, Intengan HD, Schiffrin EL. Reduction of resistance artery stiffness by treatment with the AT(1)-receptor antagonist losartan in essential hypertension. J Renin Angiotensin Aldosterone Syst. 2000;1(1):40-5.

59. Mahmud A, Feely J. Effect of angiotensin ii receptor blockade on arterial stiffness: beyond blood pressure reduction. Am J Hypertens. 2002;15(12):1092-5.

60. Capewell S, Capewell A. 'First dose' hypotension and venodilatation. Br J Clin Pharmacol. 1991;31(2):213-5.

61. Pool JL, Glazer R, Chiang YT, Gatlin M. Dose-response efficacy of valsartan, a new angiotensin II receptor blocker. J Hum Hypertens. 1999;13(4):275-81.

62. Weir MR, Weber MA, Neutel JM, Vendetti J, Michelson EL, Wang RY. Efficacy of candesartan cilexetil as add-on therapy in hypertensive patients uncontrolled on background therapy: a clinical experience trial. ACTION Study Investigators. Am J Hypertens. 2001;14(6 Pt 1):567-72.

63. Haïat R, Piot $\mathrm{O}$, Gallois H, Hanania G. Blood pressure response to the first 36 hours of heart failure therapy with perindopril versus captopril. French General Hospitals National College of Cardiologists. J Cardiovasc Pharmacol. 1999;33(6):953-9.

64. Anthopoulos L, Apostolou T, Bonoris P, Foussas S, Lefkos $\mathrm{N}$, Zombolos S. Comparative haemodynamic responses to the first dose of short- and long-acting ACE inhibitors in patients with congestive heart failure. Curr Med Res Opin. 2001;17(4):290-7.

65. Darowski A, Chambers SA, Chambers DJ. Antidepressants and falls in the elderly. Drugs Aging. 2009;26(5):381-94.

66. Marano G, Traversi G, Romagnoli E, et al. Cardiologic side effects of psychotropic drugs. J Geriatr Cardiol. 2011;8(4):24353. https://doi.org/10.3724/SP.J.1263.2011.00243.

67. Briggs R, Carey D, McNicholas T, Claffey P, Nolan H, Kennelly SP, Kenny RA. The association between antidepressant use and orthostatic hypotension in older people: a matched cohort study. J Am Soc Hypertens. 2018;12(8):597-604.e1.

68. Briggs R, Carey D, Kennelly SP, Kenny RA. Longitudinal association between orthostatic hypotension at 30 seconds post-standing and late-life depression. Hypertension. 2018;71(5):946-54.

69. Pacher P, Ungvari Z, Kecskemeti V, Koller A. Serotonin reuptake inhibitor, fluoxetine, dilates isolated skeletal muscle arterioles. Possible role of altered Ca2+ sensitivity. Br J Pharmacol. 1999;127(3):740-6.

70. Ungvari Z, Pacher P, Kecskeméti V, Koller A. Fluoxetine dilates isolated small cerebral arteries of rats and attenuates constrictions to serotonin, norepinephrine, and a voltage-dependent $\mathrm{Ca}(2+)$ channel opener. Stroke. 1999;30(9):1949-54.
71. Pacher P, Ungvari Z, Nanasi PP, Furst S, Kecskemeti V. Speculations on difference between tricyclic and selective serotonin reuptake inhibitor antidepressants on their cardiac effects. Is there any? Curr Med Chem. 1999;6(6):469-80.

72. Fuller RW, Holland DR, Yen TT, Bemis KG, Stamm NB. Antihypertensive effects of fluoxetine and L-5-hydroxytryptophan in rats. Life Sci. 1979;25:1237-42.

73. Hiemke C, Baumann P, Bergemann N, Conca A, Dietmaier O, Egberts K, Fric M, Gerlach M, Greiner C, Gründer G, Haen E, Havemann-Reinecke U, Jaquenoud Sirot E, Kirchherr H, Laux G, Lutz UC, Messer T, Müller MJ, Pfuhlmann B, Rambeck B, Riederer P, Schoppek B, Stingl J, Uhr M, Ulrich S, Waschgler $\mathrm{R}$, Zernig G. AGNP consensus guidelines for therapeutic drug monitoring in psychiatry: update 2011. Pharmacopsychiatry. 2011;44(6):195-235.

74. Johnson EM, et al. Cardiovascular changes associated with venlafaxine in the treatment of late-life depression. Am J Geriatr Psychiatry. 2006;14(9):796-802.

75. Raskin J, Wiltse CG, Dinkel JJ, Walker DJ, Desaiah D, Katona C. Safety and tolerability of duloxetine at $60 \mathrm{mg}$ once daily in elderly patients with major depressive disorder. J Clin Psychopharmacol. 2008;28(1):32-8.

76. Alexandrino-Silva C, Nadalini Mauá FH, de Andrade AG, de Toledo Ferraz Alves TC. Hypotension caused by therapeutic doses of venlafaxine: case report and proposed pathophysiological mechanisms. J Psychopharmacol. 2008;22(2):214-6.

77. Brunton LL, Parker KL, Blumenthal DK, Buxton ILO. Goodman and Gilman's manual of pharmacology and therapeutics. 12th ed. New York: The Mac Graw Hill Company; 2011.

78. Haria M, Fitton A, McTavish D. Trazodone. A review of its pharmacology, therapeutic use in depression and therapeutic potential in other disorders. Drugs Aging. 1994;4(4):331-55.

79. Fagiolini A, Comandini A, Catena Dell'Osso M, Kasper S. Rediscovering trazodone for the treatment of major depressive disorder. CNS Drugs. 2012;26(12):1033-49.

80. Hartke RH Jr, Gonzalez-Rothi RJ, Abbey NC. Midazolam-associated alterations in cardiorespiratory function during colonoscopy. Gastrointest Endosc. 1989;35(3):232-8.

81. Marty J, Gauzit R, Lefevre P, Couderc E, Farinotti R, Henzel C, Desmonts JM. Effects of diazepam and midazolam on baroreflex control of heart rate and on sympathetic activity in humans. Anesth Analg. 1986;65(2):113-9.

82. Samuelson PN, Reves JG, Smith LR, Kouchoukos NT. Midazolam versus diazepam: different effects on systemic vascular resistance. A randomized study utilizing cardiopulmonary bypass constant flow. Arzneimittelforschung. 1981;31(12a):2268-9.

83. Rivasi G, Kenny RA, Ungar A, Romero-Ortuno R. Effects of benzodiazepines on orthostatic blood pressure in older people. Eur J Intern Med. 2020;72:73-8.

84. Shi SJ, Garcia KM, Meck JV. Temazepam, but not zolpidem, causes orthostatic hypotension in astronauts after spaceflight. J Cardiovasc Pharmacol. 2003;41(1):31-9.

85. Zeegers A, van Wilgenburg H, Leeuwin RS. Cardiac effects of benzodiazepine receptor agonists and antagonists in the isolated rat heart: a comparative study. Life Sci. 1998;63(16):1439-56.

86. Harding J, Kemper M, Weissman C. Midazolam attenuates the metabolic and cardiopulmonary responses to an acute increase in oxygen demand. Chest. 1994;106(1):194-200.

87. Kamijo Y, Masuda T, Nishikawa T, Tsuruta H, Ohwada T. Cardiovascular response and stress reaction to flumazenil injection in patients under infusion with midazolam. Crit Care Med. 2000;28(2):318-23.

88. Lechin F, van der Dijs B, Benaim M. Benzodiazepines: tolerability in elderly patients. Psychother Psychosom. 1996;65(4):171-82. 
89. Mackin P. Cardiac side effects of psychiatric drugs. Hum Psychopharmacol. 2008;23(Suppl 1):3-14.

90. Leung JY, Barr AM, Procyshyn RM, Honer WG, Pang CC. Cardiovascular side-effects of antipsychotic drugs: the role of the autonomic nervous system. Pharmacol Ther. 2012;135(2):113-22.

91. Gugger JJ. Antipsychotic pharmacotherapy and orthostatic hypotension: identification and management. CNS Drugs. 2011;25(8):659-71.

92. Silver H, Kogan H, Zlotogorski D. Postural hypotension in chronically medicated schizophrenics. J Clin Psychiatry. 1990;51:459-62.

93. Wood LD. Clinical review and treatment of select adverse effects of dopamine receptor agonists in Parkinson's disease. Drugs Aging. 2010;27(4):295-310.

94. Churchyard A, Mathias CJ, Boonkongchuen P, Lees AJ. Autonomic effects of selegiline: possible cardiovascular toxicity in Parkinson's disease. J Neurol Neurosurg Psychiatry. 1997;63(2):228-34.

95. Churchyard A, Mathias CJ, Lees AJ. Selegiline-induced postural hypotension in Parkinson's disease: a longitudinal study on the effects of drug withdrawal. Mov Disord. 1999;14(2):246-51.

96. Abassi ZA, Binah O, Youdim MB. Cardiovascular activity of rasagiline, a selective and potent inhibitor of mitochondrial monoamine oxidase B: comparison with selegiline. Br J Pharmacol. 2004;143(3):371-8.

97. Perez-Lloret S, Rey MV, Fabre N, Ory F, Spampinato U, Senard JM, Pavy-Le Traon A, Montastruc JL, Rascol O. Factors related to orthostatic hypotension in Parkinson's disease. Parkinsonism Relat Disord. 2012;18(5):501-5.

98. Curcio F, Testa G, Ceccofiglio A, Martone AM, Riccio D, Nicosia F, Noro G, Bellelli G, Bo M, Mussi C, Landi F, Ungar A, Abete P. Memantine induces reflex syncope in elderly patients with dementia: results from the syncope and dementia study (SYD-Study). J Am Med Dir Assoc. 2020;21(1):130-2.

99. Sharma NM, Cunningham CJ, Zheng H, et al. Hypoxia-inducible Factor-1a mediates increased sympathoexcitation via glutamatergic N-Methyld-Aspartate receptors in the paraventricular nucleus of rats with chronic heart failure. Circ Heart Fail. 2016;9:e003423.

100. Gallini A, Sommet A, Montastrue JL. French PharmacoVigilance network: does memantine induce bradycardia? Pharmacoepidemiol Drug Saf. 2008;17:877-81.

101. Huang CF, Su MJ. Positive ionotropic action of NMDA receptor antagonist (+)-MK801 in rat heart. J Biomed Sci. 1999;6:387-98.

102. Eschlböck S, Wenning G, Fanciulli A. Evidence-based treatment of neurogenic orthostatic hypotension and related symptoms. J Neural Transm (Vienna). 2017;124(12):1567-605.

103. Gibbons $\mathrm{CH}$, Schmidt P, Biaggioni I, Frazier-Mills C, Freeman $\mathrm{R}$, Isaacson $\mathrm{S}$, et al. The recommendations of a consensus panel for the screening, diagnosis, and treatment of neurogenic orthostatic hypotension and associated supine hypertension. J Neurol. 2017;264(8):1567-82.

104. Magkas N, Tsioufis C, Thomopoulos C, Dilaveris P, Georgiopoulos G, Sanidas E, et al. Orthostatic hypotension: From pathophysiology to clinical applications and therapeutic considerations. J Clin Hypertens. 2019;21:546-54.

105. Ali A, Ali NS, Waqas N, Bhan C, Iftikhar W, Sapna F, et al. Management of orthostatic hypotension: a literature review. Cureus. 2018;10(8):e3166.

106. Pittner H, Stormann H, Enzenhofer R. Pharmacodynamic actions of midodrine, a new alpha-adrenergic stimulating agent, and its main metabolite, ST 1059. Arzneimittelforschung. 1976;26(12):2145-54.

107. Wright RA, Kaufmann HC, Perera R, Opfer-Gehrking TL, McElligott MA, Sheng KN, et al. A double-blind, dose-response study of midodrine in neurogenic orthostatic hypotension. Neurology. 1998;51(1):120-4.

108. Low PA, Gilden JL, Freeman R, Sheng KN, McElligott MA. Efficacy of midodrine vs placebo in neurogenic orthostatic hypotension. A randomized, double-blind multicenter study. Midodrine Study Group. JAMA. 1997;277(13):1046-51.

109. Jankovic J, Gilden JL, Hiner BC, Kaufmann H, Brown DC, Coghlan $\mathrm{CH}$, et al. Neurogenic orthostatic hypotension: a double-blind, placebo-controlled study with midodrine. Am J Med. 1993;95(1):38-48.

110. Fouad-Tarazi FM, Okabe M, Goren H. Alpha sympathomimetic treatment of autonomic insufficiency with orthostatic hypotension. Am J Med. 1995;99(6):604-10.

111. Fanciulli A, Jordan J, Biaggioni I, Calandra-Buonaura G, Cheshire WP, Cortelli P, et al. Consensus statement on the definition of neurogenic supine hypertension in cardiovascular autonomic failure by the American Autonomic Society (AAS) and the European Federation of Autonomic Societies (EFAS): Endorsed by the European Academy of Neurology (EAN) and the European Society of Hypertension (ESH). Clin Auton Res. 2018;28(4):355-62. https://doi.org/10.1007/s10286-018-0529-8.

112. Ricci F, De Caterina R, Fedorowski A. Orthostatic hypotension: epidemiology, prognosis, and treatment. J Am Coll Cardiol. 2015;66(7):848-60.

113. Freeman R, Landsberg L, Young J. The treatment of neurogenic orthostatic hypotension with 3,4-DL-threo-dihydroxyphenylserine: a randomized, placebo-controlled, crossover trial. Neurology. 1999;53(9):2151-7.

114. Kaufmann H, Saadia D, Voustianiouk A, Goldstein DS, Holmes $\mathrm{C}$, Yahr MD, et al. Norepinephrine precursor therapy in neurogenic orthostatic hypotension. Circulation. 2003;108(6):724-8.

115. Kaufmann H, Freeman R, Biaggioni I, Low P, Pedder S, Hewitt LA, et al. Droxidopa for neurogenic orthostatic hypotension: a randomized, placebo-controlled, phase 3 trial. Neurology. 2014;83(4):328-35.

116. Hauser RA, Isaacson S, Lisk JP, Hewitt LA, Rowse G. Droxidopa for the short-term treatment of symptomatic neurogenic orthostatic hypotension in Parkinson's disease (nOH306B). Mov Disord. 2015;30(5):646-54

117. Biaggioni I, Freeman R, Mathias CJ, Low P, Hewitt LA, Kaufmann $\mathrm{H}$, et al. Randomized withdrawal study of patients with symptomatic neurogenic orthostatic hypotension responsive to droxidopa. Hypertension. 2015;65(1):101-7.

118. Hauser RA, Hewitt LA, Isaacson S. Droxidopa in patients with neurogenic orthostatic hypotension associated with Parkinson's disease (NOH306A). J Parkinsons Dis. 2014;4(1):57-65.

119. Mathias CJ, Senard JM, Braune S, Watson L, Aragishi A, Keeling JE, et al. L-threo-dihydroxyphenylserine (L-threo-DOPS; droxidopa) in the management of neurogenic orthostatic hypotension: a multi-national, multi-center, dose-ranging study in multiple system atrophy and pure autonomic failure. Clin Auton Res. 2001;11(4):235-42.

120. Biaggioni I, Robertson D. Endogenous restoration of noradrenaline by precursor therapy in dopamine-beta-hydroxylase deficiency. Lancet (Lond, Engl). 1987;2(8569):1170-2.

121. Kachi T, Iwase S, Mano T, Sakoda S, Hayashi A, Yamamura $\mathrm{Y}$, et al. Effect of L-threo-3,4-dihydroxyphenylserine on muscle sympathetic nerve activities in Shy-Drager syndrome. Neurology. 1988;38(7):1091-4.

122. Kaufmann H, Oribe E, Yahr MD. Differential effect of L-threo3,4-dihydroxyphenylserine in pure autonomic failure and multiple system atrophy with autonomic failure. J Neural Transm Park Dis Dement Sect. 1991;3(2):143-8.

123. Keating GM. Droxidopa: a review of its use in symptomatic neurogenic orthostatic hypotension. Drugs. 2015;75(2):197-206. 
124. Hale GM, Valdes J, Brenner M. The treatment of primary orthostatic hypotension. Ann Pharmacother. 2017;51(5):417-28.

125. Chobanian AV, Volicer L, Tifft CP, Gavras H, Liang CS, Faxon D. Mineralocorticoid-induced hypertension in patients with orthostatic hypotension. N Engl J Med. 1979;301(2):68-73.

126. Campbell IW, Ewing DJ, Clarke BF. 9-Alpha-fluorohydrocortisone in the treatment of postural hypotension in diabetic autonomic neuropathy. Diabetes. 1975;24(4):381-4.

127. Ong AC, Myint PK, Shepstone L, Potter JF. A systematic review of the pharmacological management of orthostatic hypotension. Int J Clin Pract. 2013;67(7):633-46.

128. Hakamäki T, Rajala T, Lehtonen A. Ambulatory 24-hour blood pressure recordings in patients with Parkinson's disease with or without fludrocortisone. Int J Clin Pharmacol Ther. 1998;36(7):367-9.

129. Ten Harkel AD, Van Lieshout JJ, Wieling W. Treatment of orthostatic hypotension with sleeping in the head-up tilt position, alone and in combination with fludrocortisone. J Intern Med. 1992;232(2):139-45.

130. van Lieshout JJ, ten Harkel ADJ, Wieling W. Fludrocortisone and sleeping in the head-up position limit the postural decrease in cardiac output in autonomic failure. Clin Auton Res. 2000;10:35-42.

131. Singer W, Opfer-Gehrking TL, McPhee BR, Hilz MJ, Bharucha AE, Low PA. Acetylcholinesterase inhibition: a novel approach in the treatment of neurogenic orthostatic hypotension. J Neurol Neurosurg Psychiatry. 2003;74(9):1294-8.

132. Singer W, Sandroni P, Opfer-Gehrking TL, Suarez GA, Klein $\mathrm{CM}$, Hines S, et al. Pyridostigmine treatment trial in neurogenic orthostatic hypotension. Arch Neurol. 2006;63(4):513-8.

133. Singer W, Opfer-Gehrking TL, Nickander KK, Hines SM, Low PA. Acetylcholinesterase inhibition in patients with orthostatic intolerance. J Clin Neurophysiol. 2006;23(5):476-81.

134. Alam M, Smith G, Bleasdale-Barr K, Pavitt DV, Mathias CJ. Effects of the peptide release inhibitor, octreotide, on daytime hypotension and on nocturnal hypertension in primary autonomic failure. J Hypertens. 1995;13(12 Pt 2):1664-9.

135. Mathias CJ, Fosbraey P, da Costa DF, Thornley A, Bannister R. The effect of desmopressin on nocturnal polyuria, overnight weight loss, and morning postural hypotension in patients with autonomic failure. Br Med J (Clin Res Ed). 1986;293(6543):353-4.

136. Hoeldtke RD, Streeten DH. Treatment of orthostatic hypotension with erythropoietin. N Engl J Med. 1993;329(9):611-5.

137. Rao SV, Stamler JS. Erythropoietin, anemia, and orthostatic hypotension: the evidence mounts. Clin Auton Res. 2002;12(3):141-3. 